\title{
Expression of Putative Stem Cell Markers Related to Developmental Stage of Sheep Mammary Glands
}

\author{
M. Colitti* \\ Address of author: Department of Scienze Animali, Faculty of Veterinary Medicine, University of Udine, via delle Scienze, 208, 33100 \\ Udine, Italy
}

\begin{abstract}
*Correspondence:
Tel.: +39 0432558583; fax: +390432558585;

e-mail: monica.colitti@uniud.it
\end{abstract}

With 2 figures and 2 tables

Received July 2010; accepted for publication July 2010

doi: 10.1111/j.1439-0264.2010.01028.x

\begin{abstract}
Summary
It is thought that the regenerative capacity of the mammary gland following post-lactation involution resides in multipotent stem cells within the luminal tissue. Adult stem cells make up a small percentage of the cells found in mature organ systems, however to define useful markers has long been a challenge. c-Kit (KIT) and its ligand stem cell factor (KITLG), ATP-binding cassette sub-family G member 2 (ABCG2) and Musashi 1 (MSI1) are good candidate to identify progenitor cells in their niche. Using real-time PCR we showed that KIT, KITLG and MSIl expressions were up regulated before lambing and at involution relatively to prepubertal stage. The in situ hybridization analysis for KIT gene confirmed and localized the expression in luminal epithelial cells. The changes in the expression profile of putative stem cell markers in mammary glands of sheep suggest that they modify with the progression of lactation cycle, being up regulated during differentiation and down regulated during lactation.
\end{abstract}

\section{Introduction}

During the entire life cycle of the mammary gland, competent mammary stem cells are presumed to exist to provide for expansion of cell populations and cell turnover or replacement. In fact, mammary glands have high regenerative capacity during pregnancy and lactation (Holland et al., 2003). Because dairy animals undergo reproductive cycles for milk production, they are an excellent model to examine physiologic characteristics of mammary glands.

Based on their ultrastructural analyses, Chepko and Smith (1997, 1999) proposed that small, light staining cells (SLC) within the mammary parenchyma act as multipotent mammary stem cells. Other mammary epithelial cell types were classified as undifferentiated large light cells (ULLC), differentiated large light cells (DLLC), differentiated secretory cells or large dark cells (LDC) and myoepithelial cells. It was suggested that a morphologically indistinguishable subset of SLC act as primary progenitors and give rise to the ULLC. In turn, the ULLC divide multiple times to expand the parenchymal cell population and produce more LDC or myoepithelial cells.
In addition, Ellis and Capuco (2002) strongly supported the hypothesis that the SLC function as the primary proliferative cell populations also in heifers. However, morphologically, it is quite impossible to distinguish the stem cells from the terminally differentiated cells of a particular tissue.

A number of investigators have attempted to isolate molecular markers for mammary stem cells ( $\mathrm{Li}$ et al., 1998; Welm et al., 2003), but till now, no genetic marker has yet been found to positively identify mammary stem cells in situ. Positive stem cell markers such as c-kit (the receptor for stem cell factor, KIT) are used to distinguish stem cells, isolate them and study their function. KIT, also known as CD117, is a growth factor receptor of the tyrosine kinase subclass III family, normally expressed in a variety of human tissues including hematopoietic stem cells, mast cells, gametocytes, melanocytes and the interstitial cells of Cajal. KIT is activated by its ligand, stem cell factor (KITLG), and plays various roles in haematopoiesis, melanogenesis, spermatogenesis and the development of the interstitial cells of Cajal (Ronnstrand, 2004). KIT signalling promotes cell survival, proliferation, differentiation, adhesion and migration (Ashman, 1999). 
Localization of ABCG2 (also known as BCRP1 for breast cancer resistance protein), a member of the family of ATP-binding cassette (ABC) transporters, was detected in normal tissues, such as the colon epithelium, placenta syncytiotrophoblast, small intestine epithelium, liver (bile canaliculi), mammary gland (lobules and lactiferous ducts), vein endothelium and capillaries (Maliepaard et al., 2001) and mouse renal tubules (Jonker et al., 2002). ABCG2 expression is highly induced in the apical membrane of alveolar epithelial cells during late pregnancy and especially during lactation (Jonker et al., 2005), and it is involved in the secretion of drugs into milk. ABCG2 is also associated with the side population (SP), a phenotype of stem cells displaying low Hoechst 33342 accumulation (Zhou et al., 2001; Scharenberg et al., 2002), as in human heart, ABCG2 is involved in cellular export of Hoechst 3352. Therefore, ABCG2 may now serve as a marker protein for SP cell selection (Zhou et al., 2002).

Musashi 1 (MSI1) has been studied as marker involved in mammary stem cell detection since it was found to be expressed by epithelial progenitors in intestine, gastric mucosa, mammary glands, hair follicles and in human endometrium (Potten et al., 2003; Clarke et al., 2005; Nagata et al., 2006; Sugiyama-Nakagiri et al., 2006; Götte et al., 2008). Recently we found that MSI1 is expressed in a different degree, in mammary gland of ewes from prepubertal stage to involution (Colitti and Farinacci, 2009). Wang et al. (2008) indicated that MSI1 promote the expression of a number of genes associated with cell cycle, development and cell adhesion. In fact, up-regulation of MSI1 is associated with increased activity of Nocth and Wnt signalling, the net result being the stimulation of mammary progenitor cell proliferation.

The present study comprehensively describes, by realtime PCR, the putative stem cell markers expression profile in mammary glands of sheep at different developmental stages, relatively to prepubertal stage. In addition, the KIT mRNA detected by in situ hybridization, was also localized at each stages.

\section{Materials and Methods}

Animals

Tissue was collected from mammary glands of thirty Sardinian sheep that were slaughtered at different developmental stages: prepubertal (30 \pm 5 days, group P), 10 days before lambing (group LateP), 30, 60, 150 DIM (groups 30L, 60L, 150L, respectively) and 8 days after the end of lactation (group 8IN). For each of these sampling periods, five animals were randomly selected from a flock of grazing sheep and a clinical examination was conducted in vivo to ascertain animal health and to exclude mastitis. Sardinian sheep are a breed primarily used to produce milk; in this study milk yield ranged from 1600 to $900 \mathrm{~g} /$ day at 150 days in milk (DIM). Ewes at 30 DIM were allowed to suckle their lamb; the other groups $(60 \mathrm{~L}$, 150L) were mechanically milked twice daily and manually $10 \mathrm{~min}$ before slaughtering, therefore, just before tissue collection (Pulina et al., 2009).

Two samples of tissue were collected, one was collected in TRIzol ${ }^{\circledR}$ (Invitrogen, Milan, Italy), then frozen in liquid nitrogen and the other one fixed in $10 \%$ neutral formalin. The experiment was carried out in accordance with state and local laws and ethical regulations (DL No. 116, 128 27/01/1992).

\section{RNA extraction and primer design}

Total RNA was extracted from mammary tissue using TRIzol® Plus RNA Purification System (Invitrogen), following the manufacturer's instructions. The concentration of the extracted total RNA was quantified with a spectrophotometer (NanoDrop 1000 ThermoScientific, Wilmington, DE, USA). RNA integrity was evaluated by the observation of $18 \mathrm{~S}$ and $28 \mathrm{~S}$ ribosomal bands after electrophoresis on $1 \%$ agarose gel in the presence of ethidium bromide. In sample analysis, $\beta$-actin (AF035422) expression was used as an internal control, confirming the integrity of the RNA.

Primer3 Input software (Rozen and Skaletsky, 2000) was used to design the primer sequences encoding for the KIT (AM293661), KITLG (Z50743), ABCG2 (DQ886530), MSI1 (AB240581) 18SrRNA (AM711875). Primers and product lengths for each gene are listed in Table 1 according to HUGO Gene Nomenclature Committee.

\section{Reverse transcriptase-PCR and riboprobe synthesis}

RT-PCR reactions were performed using a 'One step' RTPCR (Invitrogen) kit. For each reaction, total RNA ( $1 \mu \mathrm{g})$ from ovine mammary tissue was retro-transcribed $\left(50^{\circ} \mathrm{C}\right.$ for $30 \mathrm{~min}$ ) and amplified following a PCR protocol by a MJ thermal cycler (PT-100; MJ Research, Inc., Waltham, MA, USA). PCR reactions carried out with the RNA samples, using this set of primers, did not give any amplification product, ruling out the possibility that the observed bands might be due to the presence of contaminant genomic DNA. The RT-PCR product (205 bp) for KIT was purified from agarose with Wizard ${ }^{\circledR}$ SV Gel Clean-Up System (Promega, Milan, Italy), cloned using a dual promoter TOPO TA cloning kit containing pCRII-TOPO cloning vector (Invitrogen, Groningen, The Netherlands). The insert was sequenced (Primm, Milan, Italy) to verify probe specificity and orientation.

To prepare sense and anti-sense RNA probes, the transcripts were digoxigenin-labelled by in vitro transcription 
Table 1. Oligonucleotide primer sequences for SybrGreen qRT-PCR (KIT, proto-oncogene tyrosineprotein kinase kit; KITLG, stem cell factor; ABCG2, ATP-binding cassette sub-family $\mathrm{G}$ member 2; MSI1, musashi homolog 1; $18 \mathrm{~S}$ rRNA, 185 subunit rRNA, ACTB actin beta)

\begin{tabular}{|c|c|c|c|}
\hline Gene & Primer sets & $\begin{array}{l}\text { Product } \\
\text { length (bp) }\end{array}$ & $\begin{array}{l}\text { GeneBank } \\
\text { gi-number }\end{array}$ \\
\hline KIT & $\begin{array}{l}\text { Forward: 5'AGGGACTGAAGGAGGCACTT 3' } \\
\text { Reverse: 5' AGAACACCTCTGCTCGGTTC 3' }\end{array}$ & 205 & 110681494 \\
\hline KITLG & $\begin{array}{l}\text { Forward: 5' GGTGGCAAATCTTCCAAAAG 3' } \\
\text { Reverse: 5' TCTTCCATGCACTCCACAAG 3' }\end{array}$ & 222 & 14993549 \\
\hline$A B C G 2$ & $\begin{array}{l}\text { Forward: 5' GACCTGCAGACGTTGACTGA 3' } \\
\text { Reverse: 5'ATGTGGATCCTTCCTTGCAG 3' }\end{array}$ & 222 & 115589695 \\
\hline MSI1 & $\begin{array}{l}\text { Forward: 5' GTTTCGGCTTCGTCACTTTC 3' } \\
\text { Reverse: 5' TCCACCGTGGTGTTTACTGA 3' }\end{array}$ & 184 & 124358512 \\
\hline $18 \mathrm{~S}$ rRNA & $\begin{array}{l}\text { Forward: 5'AAACGGCTACCACATCCAAG 3' } \\
\text { Reverse: 5' TCCTGTATTGTTATTTTTCGTCAC 3' }\end{array}$ & 90 & 58760943 \\
\hline ACTB & $\begin{array}{l}\text { Forward: 5' TCCCTGGAGAAGAGCTACGA 3' } \\
\text { Reverse: 5'AGCACCGTGTTGGGATAGAG 3' }\end{array}$ & 102 & 2182268 \\
\hline
\end{tabular}

using a DIG RNA Labelling kit (Roche Diagnostics, Milan, Italy) and T7 and SP6 polymerase. The riboprobe concentration was evaluated by spectrophotometric analysis and stored at $-80^{\circ} \mathrm{C}$. The yields of labelled probes were determined by spotting a serial dilution of the probes on a nylon membrane followed by an enzyme-linked immunoassay with anti-DIG AP and BCIP/NBT (DIG RNA labelling Kit; Roche).

\section{In situ hybridization}

In situ hybridization was used to localize KIT mRNAs in sheep mammary gland sections using digoxygenin (DIG)labelled sense and anti-sense KIT probes.

The probes, generated by RT-PCR analysis, were used to hybridize the samples embedded in paraffin and cut at $5 \mu \mathrm{m}$. Briefly, the slides were dewaxed with xylene and rehydrated in decreasing concentrations of ethanol till diethylpyrocarbonate (DECP)-treated water. The permeabilization was performed in Tris-EDTA buffer (TE) with $10 \mu \mathrm{g} / \mathrm{ml}$ of RNase free proteinase $\mathrm{K}$ at $37^{\circ} \mathrm{C}$ for $30 \mathrm{~min}$. Post-fixation treatment was performed in a solution of $4 \%$ paraformaldehyde at $4^{\circ} \mathrm{C}$ for $15 \mathrm{~min}$, and after acetylation, the sections were incubated at $37^{\circ} \mathrm{C}$ for $1 \mathrm{~h}$ in prehybridization buffer containing 20\% formamide (v/v), $6 \mathrm{X}$ SSC, 2X Denhardt's solution, $400 \mu \mathrm{g} / \mathrm{ml}$ of denatured ssDNA, 5\% dextran sulfate $(\mathrm{w} / \mathrm{v})$ and $0.5 \%$ Tween 20 . Hybridization was performed overnight at $55^{\circ} \mathrm{C}$ in a humidified chamber in the same buffer containing $2 \mathrm{ng} / \mathrm{ml}$ digoxingenin-labelled sense or anti-sense probe.

Sections were washed in a shaking water bath in $2 \mathrm{X}$ saline-sodium citrate buffer (SSC) at $37^{\circ} \mathrm{C}, 0.5 \mathrm{X}$ SSC, $0.25 \mathrm{X}$ SSC at room temperature (RT) and then, to digest the unbound RNA probe, incubated in NTE buffer (10 mm Tris- $\mathrm{HCl}, \mathrm{pH} 8.0,0.5 \mathrm{M} \mathrm{NaCl}$ and $1 \mathrm{~mm}$ EDTA) containing $20 \mu \mathrm{g} / \mathrm{ml}$ RNase A. The last washing was performed in $0.1 \mathrm{X}$ SSC. After incubation for $30 \mathrm{~min}$ with 5\% blocking reagent (Roche Diagnostics) in Trisbuffered solution (TBS), the sections were incubated overnight at $4^{\circ} \mathrm{C}$ in the anti-digoxigenin alkaline phosphatase conjugated antibody (Roche Diagnostics) diluted 1:500 in TBS containing $1 \%$ blocking reagent. After washes, alkaline phosphatase was detected by incubation in 5-Bromo-4-Chloro, Nitro Blue Tetrazolium Chloride (NBT/BCIP) containing $0.01 \mathrm{~m}$ levamisole, overnight in the dark. The colour reaction was stopped by washing in water for $5 \mathrm{~min}$. Slides were then counterstained in $0.1 \%(\mathrm{w} / \mathrm{v})$ of nuclear fast red, mounted using an aqueous solution and photographed with an Olympus DP10 digital camera.

The specificity was verified by substituting the labelled sense riboprobe for the anti-sense probe.

\section{Real-time PCR quantitation}

Reverse transcriptions were performed with $1 \mu \mathrm{g}$ of extracted total RNA by using Improm-II Reverse Transcriptase (Promega) according to the manufacturer's instructions. The final concentration of cDNA was assumed as $50 \mathrm{ng} / \mu \mathrm{l}$.

For every gene, an aliquot of each cDNA samples were pooled and standard curves with serial dilution of pool were used to optimize PCR conditions and to calculate the efficiency, fluorescence baseline and threshold.

Real-time RT-PCR reactions were performed in triplicate using Platinum ${ }^{\circledR}$ SYBR ${ }^{\circledR}$ Green qPCR SuperMixUDG (Invitrogen). PCR conditions were: denaturation at $95^{\circ} \mathrm{C}$ for $2 \mathrm{~min}$, amplification and quantification programs with 45 cycles of $95^{\circ} \mathrm{C}$ for $1 \mathrm{~s}$, each of annealing temperature for $30 \mathrm{~s}$, extension at $72^{\circ} \mathrm{C}$ for $30 \mathrm{~s}$. Melting curve analysis of amplification products was performed at the end of each PCR reaction to confirm that a single PCR product was detected. Reactions were conducted in singleplex in a 96-well spectrofluorometric thermal cycler 
(DNA Engine Opticon 2; MJ Research, Inc., Waltham, MA, USA).

The expression of target genes was normalized using the 18S rRNA gene, which is known to be constitutively expressed (Robinson et al., 2007). The expression level of a given target gene in each experimental group was analysed by the $2^{-\Delta \Delta C t}$ method (Bustin, 2000; Pfaffl, 2001) where $2^{-\Delta \Delta \mathrm{Ct}}$ represents the difference of a given target gene between each group after lambing (groups from LateP to $8 \mathrm{IN}$ ) versus the group P. More precisely, individual $\Delta \Delta$ Ct was calculated for each sample of group (LateP-8IN) as $\Delta \Delta \mathrm{Ct}=\Delta \mathrm{Ct}$ (sample group) - mean $\Delta \mathrm{Ct}$ (group P). The $n$-fold expression was calculated as $2^{-\Delta \Delta C t}$ for up regulated genes, and $-\left(1 / 2^{-\Delta \Delta \mathrm{Ct}}\right)$ for down regulated genes. The $n$-fold expression of a given target gene was calculated as $\log 2\left(2^{-\Delta \Delta C t}\right)$ (Fig. 2).

\section{Statistical analysis}

All the recorded variables were submitted to analysis of variance using the ANOva model to assess significant dif- ferences between groups; Duncan's least significant difference test was used to compare the means (SPSS Inc., 1997).

\section{Results}

In situ hybridization

In situ hybridization on histological sections was done using anti-sense and sense cRNA digoxigenin-labelled probes directed against the 205-bp KIT sequence. The hybridization analysis was utilized for studying the expression of the isolated mRNA in the mammary glands of sheep at P, LateP, 60L and 8IN stages. Alkaline-phosphatase-tagged RNA probes were revealed by a reddishblue colour and the staining indicative of KIT mRNA expression was cytoplasmatic (Fig. 1).

In $\mathrm{P}$ mammary tissue the anti-sense probe labelled epithelial cells of differentiating ducts as diffusely punctuate staining (Fig. 1a). Strong reaction was seen in epithelium of alveoli in LateP both in epithelial cells (Fig. 1b, arrows) and in stromal cells lining the alveoli (Fig. 1b, arrow-
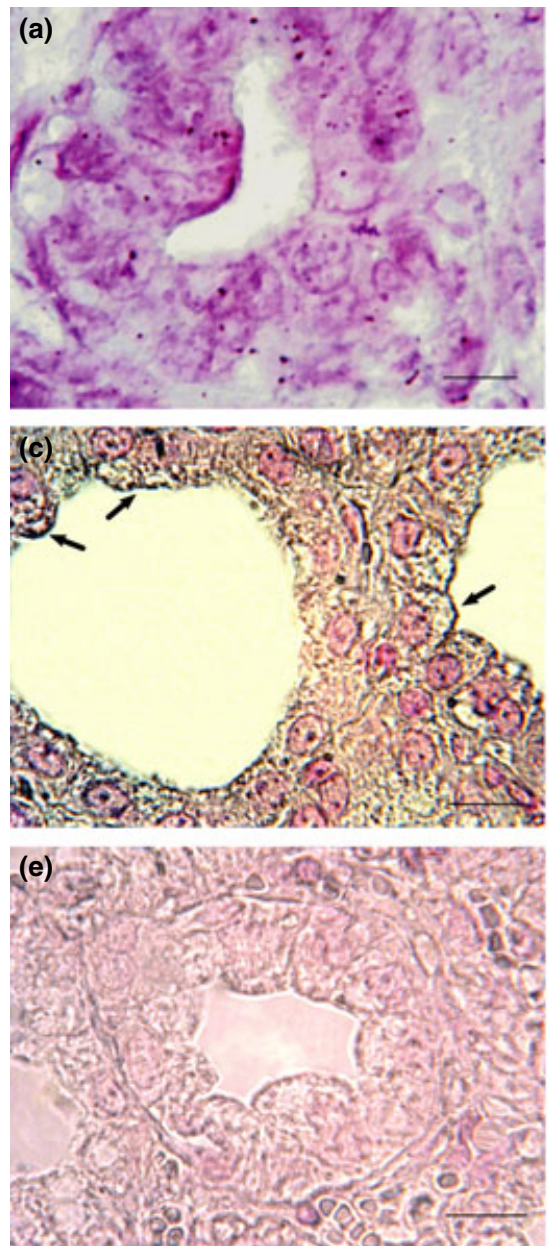
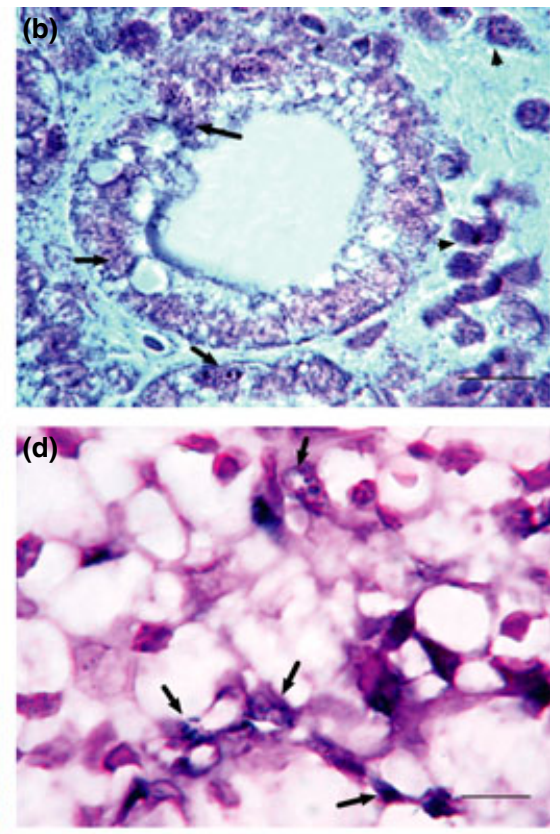

Fig. 1. KIT mRNA expression using a digoxygenin-labelled anti-sense (a-d) or sense (e) riboprobe in mammary tissue at different developmental stages. (a) At P stage staining is observed in cells of alveolar outgrowth expressing cytoplasmatic positivity (arrows).

(b) LateP, strong positive expression in alveolar epithelial cells (arrows) and in stromal cells (arrowheads) is observed. (c) Lactating gland (60L), apical cytoplsmatic staining is seen in epithelial cells. (d) At involution $(8 \mathrm{IN})$ positivity expression is observed in cells of disrupted alveoli. (e) Negative reaction is observed with sense probe. Scale bars $20 \mu \mathrm{m}$ (a), $25 \mu \mathrm{m}$ (b, c), $22 \mu \mathrm{m}$ (d) and $28 \mu \mathrm{m}$ (e). 
heads). Very faint or no positive labelling was observed during lactation $(60 \mathrm{~L})$, mostly at the apical side of the alveolar cells (Fig. 1c, arrows), whereas in 8IN group weak positive signal was present in the cytoplasm of luminal and stromal cells surrounding shrunken alveoli (Fig. 1d, arrows). The specificity of KIT anti-sense probe was ascertained using the sense probe as negative control (Fig. 1e).

\section{Expression analysis}

$18 \mathrm{~S}$ rRNA expression levels were quantified in all samples and resulted in constant expression levels. No significant differences between the groups could be shown in the investigated ovine mammary tissues.

Native agarose gel analysis of total RNA and $\beta$-actin amplification were used to verify the integrity of the mRNA extracted. Quantitative measurements of mRNAs encoding KIT, KITLG, ABCG2 and MSI1 in sheep mammary glands were obtained using real-time PCR on total mammary glands RNA samples.

Gene expression results are shown in Table 2. In terms of $\Delta \mathrm{Ct}$, KIT gene expression significantly differed $(P<0.05)$, being highest during lactation than at prepubertal stage $(\mathrm{P})$, and during involution $(8 \mathrm{IN})$. The KITLG gene abundance was significantly different $(P<0.05)$ only at LateP. The expression of ABCG2 gene significantly changed $(P<0.05)$, counter to KIT expression, being at its higher in $\mathrm{P}$ group and 8IN group. The expression of MSI1 gene was significantly affected $(P<0.05)$ by the group, being highest during lactation $(30 \mathrm{~L}, 60 \mathrm{~L}$ and $150 \mathrm{~L}$ groups) and lowest at LateP, $8 \mathrm{IN}$ and at $\mathrm{P}$.

The $n$-fold values, reported in Fig. 2 as $\log _{2}$ ( $n$-fold), indicate the relative abundance of each target gene in comparison with the $\mathrm{P}$ group. The relative transcription of KIT and ABCG2 did not change significantly among groups, being KIT down regulated and ABCG2 up regu-

Table 2. Expression level (mean $\Delta \mathrm{Ct} \pm \mathrm{SE}$ ) of putative stem cells markers in groups of sheep at different developmental stage. KIT, proto-oncogene tyrosine-protein kinase kit; KITLG, stem cell factor; ABCG2, ATP-binding cassette sub-family G member 2; MSI1, musashi homolog 1

\begin{tabular}{lrrlr}
\hline Groups & \multicolumn{1}{l}{ KIT } & \multicolumn{1}{l}{ KITLG } & \multicolumn{1}{l}{ ABCG2 } & \multicolumn{1}{l}{ MSI1 } \\
\hline P & $6.49^{\mathrm{b}} \pm 0.21$ & $6.81^{\mathrm{ab}} \pm 0.33$ & $3.62^{\mathrm{a}} \pm 0.24$ & $12.67^{\mathrm{d}} \pm 0.11$ \\
LateP & $7.60^{\mathrm{ab}} \pm 0.53$ & $5.29^{\mathrm{b}} \pm 0.29$ & $1.74^{\mathrm{b}} \pm 0.59$ & $15.67^{\mathrm{bc}} \pm 0.68$ \\
3OL & $9.05^{\mathrm{a}} \pm 0.47$ & $7.17^{\mathrm{a}} \pm 0.77$ & $1.46^{\mathrm{b}} \pm 0.52$ & $18.93^{\mathrm{a}} \pm 0.46$ \\
6OL & $8.67^{\mathrm{a}} \pm 0.51$ & $8.46^{\mathrm{a}} \pm 0.38$ & $1.41^{\mathrm{b}} \pm 0.44$ & $17.97^{\mathrm{a}} \pm 1.00$ \\
15OL & $8.97^{\mathrm{a}} \pm 0.92$ & $8.31^{\mathrm{a}} \pm 0.79$ & $1.57^{\mathrm{b}} \pm 0.63$ & $17.63^{\mathrm{ab}} \pm 1.14$ \\
8IN & $7.09^{\mathrm{b}} \pm 0.44$ & $7.61^{\mathrm{a}} \pm 0.90$ & $3.19^{\mathrm{a}} \pm 0.57$ & $15.10^{\mathrm{c}} \pm 0.42$ \\
\hline
\end{tabular}

Different superscripts within a column indicate significantly $(P<0.05)$ different means between groups. lated. The relative expression of KITLG significantly increased $(P<0.05)$ at LateP in comparison to 30, 60 and 150 days of lactation, and 8IN group. The MSI expression showed the same trend of KIT, but it was significantly transcripted $(P<0.05)$ in LateP and $8 \mathrm{IN}$ groups than in $30 \mathrm{~L}, 60 \mathrm{~L}$ and $150 \mathrm{~L}$ groups. The correlation between KIT and MSI1 was equal to 0.95 .

\section{Discussion}

Development of mammary glands is greatest during puberty with cyclical progression throughout adult life. In ewes, prepubertal mammary glands is composed by developing epithelial ducts, named 'terminal ductal unit' (TDU), which are surrounded by densely packed stromal cells embedded in a large adipose tissue (Akers, 2002; Capuco et al., 2002; Colitti and Farinacci, 2009). During pregnancy, branching networks of ducts and lobuloalveolar structures grow and are fully developed at lactation. At involution, extensive restructuring of the tissue includes the elimination of a proportion of the secretory epithelial cells by apoptosis (Colitti et al., 1999). The massive expansion of mammary epithelium during puberty and pregnancy, together with the remarkable regenerative capacity apparent during successive reproductive cycles, implicate stem-like cells (Shackleton et al., 2006). In fact, it was demonstrated that, through serial transplantations, no loss of potency was detected when compared to similar transplantations of the youngest mammary tissue tested (Boulanger and Smith, 2009).

The identification of molecular markers that best facilitate the isolation and characterization of stem cell populations has long been a question. Although previous analyses have yielded no definite markers for mammary stem cells, histological analyses have indicated that a lightly staining parenchymal cell population may function as mammary stem cells (Ellis and Capuco, 2002). Other established ability of stem cells is to efflux cellular dyes as Hoechst 33342 under ABCG2 contribution (Zhou et al., 2001; Alvi et al., 2003). Therefore, ABCG2 expression may serve as a new marker for stem cells, not only in hematopoietic cells but also in other types of cells.

In this study, we sought to investigate, by real-time PCR, the expression of some genes identified as stem cells markers in mammary tissue at different developmental stages. In addition, KIT expression was localized by in situ hybridization analysis. The quantitative expression analysis was related to prepubertal stage because it seems to be the best candidate stage of mammary gland tissue to found stem cells. In fact, as reported by Capuco (2007), some cells, displaying characteristics of stem-like cells, were identified in prepubertal bovine mammary gland. In this study, KIT, KITLG and MSI1 expressions positively 


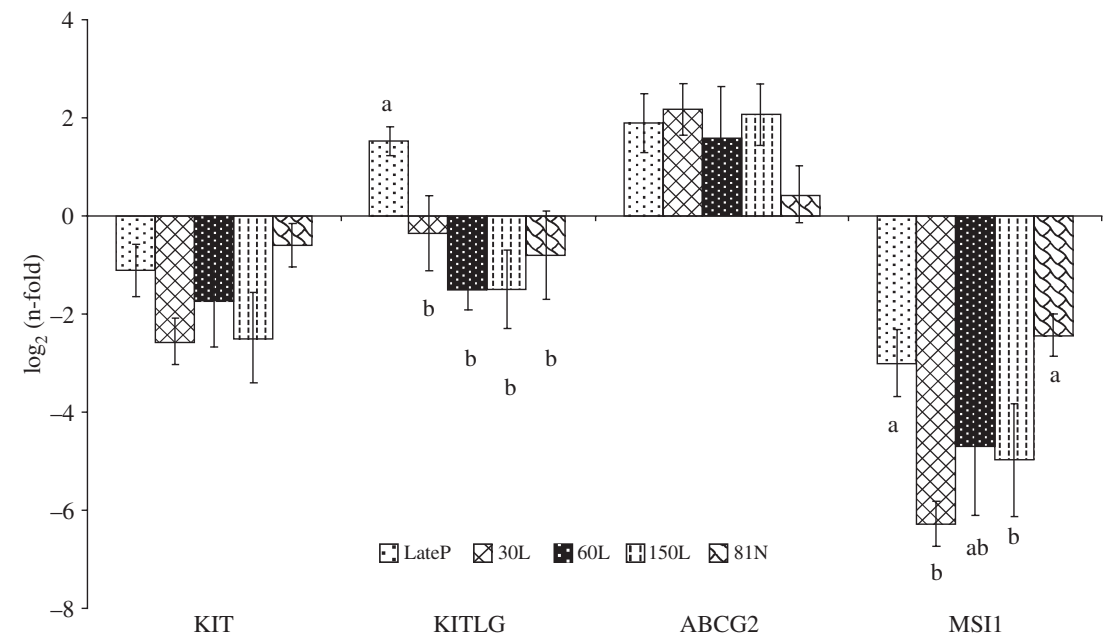

Fig. 2. Expression analysis of target genes at 10 days from lambing, 30,60, 150 days of lactation and 8 days from dry-off, related to the expression at prepubertal stage $(P)$. Late $P=10$ days from lambing; $30 \mathrm{~L}=30$ days of lactation; $60 \mathrm{~L}=60$ days of lactation; $150 \mathrm{~L}=150$ days of lactation; $8 \mathrm{IN}$ = day 8 after the dry-off. KIT, proto-oncogene tyrosine-protein kinase kit; KITLG, stem cell factor; ABCG2, ATP-binding cassette sub-family G member 2; MSI1, musashi homolog 1. Bars represent the mean \pm SE. Bars designated with different letters represent statistical differences between groups at $P<0.05$.

correlate with prepubertal stage of mammary tissue. Actually, although no evidences are present on the expression of KIT in prepubertal mammary tissue, it is known that KIT is highly expressed in normal mammary human epithelium and that an autocrine stimulation of KIT by its ligand KITLG is important for maintenance of differentiation of mammary epithelium (Ulivi et al., 2004). It has been demonstrated that KIT is essential for full activation of STAT5A (Brizzi et al., 1999) and that it has anti-apoptotic action (Jin et al., 2004) reducing the expression of BAX by inducing FOXO3a phosphorylation (Liu et al., 2009). This is in agreement with our previous results that demonstrated that in mammary gland of sheep STAT5A and BAX expressions were significantly down-regulated during lactation (Colitti and Farinacci, 2009). It is likely that the down-regulation of KITLG and KIT expressions during lactation may be related to the physiological state of the gland and contributes to maintain a balanced homeostatic state in the tissue.

The up regulation of ABCG2 is in agreement with Jonker et al. (2005) that found high alveolar expression of the ABCG2 gene in lactating, but not in virgin or nonlactating mammary glands of cow, contributing to the secretion of nutrients into the milk in spite of the coincident risk of contaminating milk with xenotoxins.

The up regulation of MSI1 at prepubertal stage could be due to the activation of Notch signalling - which is known to maintain cells in an undifferentiated state and to inhibit apoptosis - through the translational repression of m-Numb protein (an intracellular Notch antagonist), resulting in a clonal expansion of the immature stem cells.
MSI1, a putative stem/progenitor cell marker was observed in the small intestine at the fourth-sixth cell position from the bottom of the crypts and in the cells in the deepest portion of the large intestine (Potten et al., 2003). It is recently shown to be also an important positive regulator of cell proliferation and inhibitor of apoptosis. In fact, gut tumours arise from stem cells expressed at the base of intestinal and colonic crypts where MSIl is expressed. The involvement of MSI1 in colon cancer cell proliferation, inhibition of apoptosis and mitotic catastrophe, occurs through its role in inhibition of Notch signalling (Sureban et al., 2008). In mammary gland of sheep we found - using immunohistochemistry and in situ hybridization analyses - that MSI1 was expressed on mammary glands of ewes at different developmental stages and, moreover, that MSI1 $n$-fold values resulted strongly correlated $(r=0.96)$ with the expression of Ki-67 a marker of proliferation assessed for the same groups of ewes (Colitti and Farinacci, 2009).

In the present paper, MSIl, in terms of $\Delta \mathrm{Ct}$ and $n$-fold, positively correlate with lactation stages $\left(R^{2}=0.93\right)$, when it is known that proliferation prevails to apoptosis. The increase of KIT and MSI1 expression in Late $\mathrm{P}$ and in $8 \mathrm{IN}$ groups could prime mammary stem cells to differentiate, because in those stages new secretory cells are useful to lactation and to remodelling the gland.

In summary, as already underpinned by Welm et al. (2003), it is likely that the final fate of progenitors is in balance between many signalling pathways that act accordingly to regulate the process of differentiation versus self renewal. The present study provides the evidence 
that putative stem cell markers vary their expression during physiological phases of mammary cycle.

\section{Acknowledgements}

We would like to thank Prof. G. Pulina from the University of Sassari for him kind help in supplying us with the samples.

\section{References}

Akers, R. M., 2002: Lactation and the Mammary Gland. Ames, Iowa, USA: Blackwell Publishing Company.

Alvi, A. J., H. Clayton, C. Joshi, T. Enver, A. Ashworth, M. M. Vivanco, T. C. Dale, and M.J. Smalley, 2003: Functional and molecular characterisation of mammary side population cells. Breast Cancer Res. 5, R1-R8.

Ashman, L. K., 1999: The biology of stem cell factor and its receptor c-kit. Int. J. Biochem. Cell Biol. 31, 1037-1051.

Boulanger, C. A., and G. H. Smith, 2009: Reprogramming cell fates in the mammary microenvironment. Cell Cycle 8, 1-6.

Brizzi, M. F., P. Dentelli, A. Rosso, Y. Yarden, and L. Pegoraro, 1999: STAT protein recruitment and activation in c-Kit deletion mutants. J. Biol. Chem. 24, 16965-16972.

Bustin, S. A., 2000: Absolute quantification of mRNA using realtime reverse transcription polymerase chain reaction assays. J. Mol. Endocrinol. 25, 169-193.

Capuco, A. V., 2007: Identification of putative bovine mammary epithelial stem cells by their retention of labelled DNA strands. Exp. Biol. Med. 232, 1381-1390.

Capuco, A. V., S. Ellis, D. L. Wood, R. M. Akers, and W. Garrett, 2002: Postnatal mammary ductal growth: threedimensional imaging of cell proliferation, effects of estrogen treatment, and expression of steroid receptors in prepubertal calves. Tissue Cell 34, 143-154.

Chepko, G., and G.H. Smith, 1997: Three division-competent, structurally-distinct cell populations contribute to murine mammary epithelial renewal. Tissue Cell 29, 239-253.

Chepko, G., and G.H. Smith, 1999: Mammary epithelial stem cells: our current understanding. J Mammary Gland Biol. Neoplasia 4, 35-52.

Clarke, R.B., K. Spence, E. Anderson, A. Howell, H. Okano, and C. S. Potten, 2005: A putative human breast stem cell population is enriched for steroid receptor-positive cells. Dev. Biol. 277, 443-456.

Colitti, M., and M. Farinacci, 2009: Expression of a putative stem cell marker, Musashi 1, in mammary glands of ewes. J. Mol. Hist. 40, 139-149.

Colitti, M., C. J. Wilde, and B. Stefanon, 1999: Functional expression of bcl-2 protein family and AIF in bovine mammary tissue in early lactation. J. Dairy Res. 71, 20-27.

Ellis, S., and A. V. Capuco, 2002: Cell proliferation in bovine mammary epithelium: identification of the primary proliferative cell population. Tissue Cell 34, 155-163.
Götte, M., M. Wolf, A. Staebler, O. Buchweitz, R. Kelsch, A. N. Schüring, and L. Kiesel, 2008: Increased expression of the adult stem cell marker Musashi-1 in endometriosis and endometrial carcinoma. J. Pathol. 215, 317-329.

Holland, M. S., M.-H. Tai, J. E. Trosko, L. D. Griffin, J. A. Stasko, N. C. Cheville, and R. E. Holland, 2003: Isolation and differentiation of bovine mammary gland progenitor cell populations. Am. J. Vet. Res. 64, 396-403.

Jin, X., C. S. Han, F. Q. Yu, P. Wei, Z. Y. Hu, and Y. X. Liu, 2004: Anti-apoptotic action of stem cell factor on oocytes in primordial follicles and its signal transduction. Mol. Rep. Dev. 70, 82-90.

Jonker, J. W., M. Buitelaar, E. Wagenaar, M. A. Van Der Valk, G. L. Scheffer, R. J. Scheper, T. Plosch, F. Kuipers, R. P. Elferink, H. Rosing, J. H. Beijnen, and A. H. Schinkel, 2002: The breast cancer resistance protein protects against a major chlorophyll-derived dietary phototoxin and protoporphyria. Proc. Natl Acad. Sci. USA 99, 15649-15654.

Jonker, J. W., G. Merino, S. Musters, A. E. van Herwaarden, E. Bolscher, E. Wagenaar, E. Mesman, T. C. Dale, and A. H Schinkel, 2005: The breast cancer resistance protein BCRP (ABCG2) concentrates drugs and carcinogenic xenotoxins into milk. Nat. Med. 11, 127-129.

Li, P., R. Barraclough, D. G. Fernig, J. A. Smith, and P. S. Rudland, 1998: Stem cells in breast epithelia. Int. J. Exp. Pathol. 79, 193-206.

Liu, H., L. L. Luo, Y. S. Qian, Y. C. Fu, X. X. Sui, Y. J. Geng, D. N. Huang, S. T. Gao, and R. L. Zhang, 2009: FOXO3a is involved in the apoptosis of naked oocytes and oocytes of primordial follicles from neonatal rat ovaries. Biochem. Biophys. Res. Commun. 381, 722-727.

Maliepaard, M., G. L. Scheffer, I. F. Faneyte, M. A. van Gastelen, A. C. Pijnenborg, A. H. Schinkel, M. J. van De Vijver, R. J. Scheper, and J. H. Schellens, 2001: Subcellular localization and distribution of the breast cancer resistance protein transporter in normal human tissues. Cancer Res. 61, 3458-3464.

Nagata, H., Y. Akiba, H. Suzuki, H. Okano, and T. Hibi, 2006: Expression of Musashi-1 in the rat stomach and changes during mucosal injury and restitution. FEBS Lett. 580, $27-33$.

Pfaffl, M. W., 2001: A new mathematical model for relative quantification in real-time RT-PCR. Nucleic Acids Res. 29, E45.

Potten, S. C., C. Booth, G. L. Tudor, D. Booth, G. Brady, P. Hurley, G. Ashton, R. Clarke, S. Sakakibara, and H. Okano, 2003: Identification of a putative intestinal stem cell and early lineage marker; musashi-1. Differentiation 71, 28-41.

Pulina, G., M. Colitti, M. Farinacci, A. Mazzette, G. Canu, N. Castanares Castro, and A. Nudda, 2009: The evolution of mammary glands at diferent stages in sarda dairy ewes: preliminary results. Ital. J. Anim. Sci. 8(Suppl. 2), 652-654.

Ronnstrand, L., 2004: Signal transduction via the stem cell factor receptor/c-Kit. Cell. Mol. Life Sci. 61, 2535-2548. 
Rozen, S., and H. J. Skaletsky, 2000: Primer3 on the WWW for general users and for biologist programmers. In: Bioinformatics Methods and Protocols: Methods in Molecular Biology (S. Krawetz and S. Misener, eds). Totowa, NJ, USA: Humana Press, pp. 365-386.

Scharenberg, C. W., M. A. Harkey, and B. Torok-Storb, 2002: The ABCG2 transporter is an efficient Hoechst 33342 efflux pump and is preferentially expressed by immature human hematopoietic progenitors. Blood 99, 507-512.

Shackleton, M., F. Vaillant, K. J. Simpson, J. Stingl, G. K. Smyth, M. L. Asselin-Labat, L. Wu, G. J. Lindeman, and J. E. Visvader, 2006: Generation of a functional mammary gland from a single stem cell. Nature 439, 84-88.

SPSS ${ }^{\circledR}$ Statistical Package for Social Science SPSS, 1997: Advanced Statistics 7.5. Chicago, IL: SPSS Inc.

Sugiyama-Nakagiri, Y., M. Akiyama, S. Shibata, H. Okano, and H. Shimizu, 2006: Expression of RNA-binding protein Musashi in hair follicle development and hair cycle progression. Am. J. Pathol. 168, 80-92.

Sureban, S. M., S. Ramalingam, G. Natarajan, R. May, D. Subramaniam, K. S. Bishnupuri, A. R. Morrison, B. K. Dieckgraefe, D. J. Brackett, R. G. Postier, C. W. Houchen, and S. Anant, 2008: Translation regulatory factor RBM3 is a proto-oncogene that prevents mitotic catastrophe. Oncogene 27, 4544-4556.

Ulivi, P., W. Zoli, L. Medri, D. Amadori, L. Saragoni, F. Barbanti, D. Calistri, and R. Silvestrini, 2004: c-kit and SCF expression in normal and tumor breast tissue. Breast Cancer Res. Treat. 83, 33-42.

Wang, X. Y., Y. Yin, H. Yuan, T. Sakamaki, H. Okano, and R. I. Glazer, 2008: Musashil modulates mammary progenitor cell expansion through proliferin-mediated activation of the Wnt and Notch pathways. Mol. Cell. Biol. 28, 3589-3599.

Welm, B., F. Behbod, M. A. Goodell, and J. M. Rosen, 2003: Isolation and characterization of functional mammary gland stem cells. Cell Prolif. 36, 17-32.

Zhou, S., J. D. Schuetz, K. D. Bunting, A. M. Colapietro, J. Sampath, J. J. Morris, I. Lagutina, G. C. Grosveld, M. Osawa, H. Nakauchi, and B. P. Sorrentino, 2001: The ABC transporter Bcrp1/ABCG2 is expressed in a wide variety of stem cells and is a molecular determinant of the sidepopulation phenotype. Nat. Med. 7, 1028-1034.

Zhou, S., J. J. Morris, Y. Barnes, L. Lan, J. D. Schuetz, and B.P. Sorrentino, 2002: Bcrp1 gene expression is required for normal numbers of side population stem cells in mice, and confers relative protection to mitoxantrone in hematopoietic cells in vivo. Proc. Natl Acad. Sci. USA 99, 12339-12344. 